\title{
SCIENCE EDUCATION IN CONTEXT: AN OVERVIEW AND SOME OBSERVATIONS
}

\section{INTRODUCTION}

This book presents an international perspective of the influence of educational context on science education. By this we mean the context in which the teaching and learning takes place, rather than the use of a context-based approach to learning and teaching (Pilot \& Bulte, 2006). The focus is on the interactions between curriculum development and implementation in non-Western and nonEnglish-speaking contexts (i.e., outside the UK, USA, Australia, NZ, etc.).

There has been much written about the problems and issues associated with the development of curriculum, especially in science education. A complication in curriculum development and implementation is the mode of development, with the use of a centre-periphery model being common (McGee, 1997). Even with wide consultation, Bell, Jones and Carr (1995) comment that a key feature of curriculum development is the inevitable tension that arises between stakeholder groups such as: government, 'industry', curriculum developers, teachers, school authorities, teachers and students. Each of these cohorts holds certain views about what is important and what should (or should not) be included in any curriculum statement or policy document. It also is important to understand what the term curriculum means (Hume \& Coll, 2005). Here we distinguish between the formal or official curriculum (i.e., that as represented in formal policy documents), and the implemented or enacted curriculum (i.e., the interpretation of official policy statements and subsequently delivered by teachers).

Effective science curriculum is of considerable importance internationally because there is increasing pressure by governments to produce technically skilled people from the compulsory and tertiary education sectors; people capable of participating actively in the so-called 'knowledge economy'. Such pressure is often acute in 'developing' or non-Western countries, which oftentimes have economies based on the rather fickle (especially post-September 11) tourism industry, or relatively low-value agricultural produce. Factors such as isolation from major markets like Europe and the USA further exacerbates problems with economic competition - as do powerful trading blocks and the apparent inability of World Trade Organization to open markets to free competition for agricultural produce. The World Bank, in particular, routinely talks of a greater need for skilled workers in developing countries (and indeed in Western countries) for those who wish to 
participate in the knowledge economy (see, e.g., World Bank, 1996, 2006), and to shift away from commodities to value-added products.

There are similar calls for more technically skilled workers even in more developed wealthy countries. However, arguably of greater interest here is a general need to produce a scientifically-literate populace (Coll \& Taylor, 2004; Laugksch, 2000). Miller (2000) sees scientific literacy as being able to read about, understand and participate in a public policy debate involving science or technology, which many authors see as an important outcome of the school system (see Laugksch, 2000 and references therein). We live in the most scientifically and technologically advanced age ever. Incredible advances have been made in science, in medical science, technology and engineering, and information and communication technologies. Advances in education and science education have strived to incorporate these advances in science education (Fensham, 1988; Gilli, 2000). Most countries have national curricula in science, and many have witnessed the development of new national curriculum statements in related subjects such as technology (e.g. Jones, 1997; Sade \& Coll, 2003). However, many authors (e.g., Eisenhart, Finkel \& Marion, 1996; Jenkins, 1990; Preece \& Baxter, 2000; Shamos, 1996) express alarm about the prevalence of the public's beliefs that are not in accord with scientific views, seeing this lack of agreement as an unfortunate indictment of the compulsory science education sector.

\section{THEORETICAL BASIS TO THE BOOK}

Recent research seeking to understand science education has been developed based upon the notion of social cognition and sociocultural views of learning (Vygotsky, 1986; Wenger, 1991). According to social cognition theory learning occurs in a variety of contexts or situations (Hennessy, 1993; Hennessy \& Murphy, 1999). Sociocultural views of learning derived from this place considerable emphasis on the social component within the particular context or situation in which learning occurs. Educational research has in the past been grounded in the assumption that it is possible (indeed desirable) to investigate an individual removed from their social context. Many early learning theories sought to achieve this in order to obtain data 'uncontaminated' by subjective influence of researchers. Other approaches assume that cultural and social issues can be incorporated as additional variables once the basic form of mental functioning in an individual is isolated and understood. However, according to Wertsch (1991):

The basic tenet of a sociocultural approach to mind is that human mental functioning is inherently situated in social interactional, cultural, institutional, and historical context. Such a tenet contrasts with approaches that assume, implicitly or explicitly, that it is possible to examine mental processes such as thinking or memory independently of the sociocultural setting in which individuals and groups function. (p. 86)

A key feature of the book is then a focus on the 'situatedness' of learning, and its influence on curriculum. Each author writes about a particular educational issue. 
Many first provide an overview with some detail of the background about science education in the particular educational context, before exploring the influence of the key sociological and contextual factors on the issue of interest, and in some cases research projects they have been intimately involved with.

\section{ABOUT THE CONTRIBUTORS}

An important and distinguishing feature of the book is that it draws upon the experiences and research of local experts from an extremely diverse cohort across the world. Each chapter is concerned with some aspect of science curriculum (interpreted broadly to include technology, environmental and mathematics curriculum) in a specific educational context. In some cases the chapter is in the form of a story or narrative, in other case it draws from particular research inquiry conducted by the author and his or her colleagues. The book addresses topics such as: curriculum development; research or evaluation of an implemented curriculum; discussion of pressures driving curriculum reform or implementation of new curricula (e.g., technology or 'new mathematics'); the influence of political, cultural, societal or religious mores on education; governmental or ministerial drives for curriculum reform; economic or other pressures driving curriculum reform; the influence of external assessment regimes on curriculum; and so on.

The editors have made a conscious effort to remain 'hands off' when editing, and to allow the contributors own voice to be heard. This book represents their story, not ours.

\section{REFERENCES AND BIBLIOGRAPHY}

Bell, B., Jones, A., \& Carr, M. (1995). The development of the recent national New Zealand science curriculum. Studies in Science Education, 26, 73-105.

Coll, R.K., \& Taylor, N. (2004). Probing scientists' beliefs: How open-minded are modern scientists? International Journal of Science Education, 26(6), 757-778.

Duit, R. (2000). Bibliography: Student's alternative frameworks and science education (5th ed.). Kiel, Germany: University of Kiel.

Eisenhart, M., Finkel, F., \& Marion, S.F. (1996). Creating the conditions for scientific literacy: a reexamination. American Educational Research Journal, 33, 261-295.

Fensham, P.J. (1988). Familiar but different: Some dilemmas and new directions in science education. In P.J. Fensham (Ed.), Development and dilemmas in science education (pp. 1-26). London: Falmer.

Gilli, D. (2000). Science education and economic developments: Trends relationships and research agenda. Studies in Science Education, 35, 27-58.

Hennessy, S. (1993). Situated cognition and cognitive apprenticeship: Implications for classroom learning. Studies in Science Education, 22, 1-41.

Hennessy, S., \& Murphy, P. (1999). The potential for collaborative problem solving in design and technology. International Journal of Technology and Design Education, 9, 1-36.

Hume, A., \& Coll, R.K. (2005, July). The impact of a new assessment regime on science learning. Paper presented at the 34th Annual Conference of the Australasian Science Education Research Association. Hamilton, New Zealand.

Jenkins, E. (1990). Scientific literacy and school science education. School Science Review, 71, 256.

Jones, A. (1997). Recent research in learning technological concepts and processes. International Journal of Technology Design Education, 7(1-2), 83-96.

Laugksch, R.C. (2000). Scientific literacy: A conceptual overview. Science Education, 84, 71-94. 


\title{
COLL AND TAYLOR
}

Lave, J. (1991). Situated learning in communities of practice. In L.B. Resnick, J.M. Levine \& S.D. Teasly (Eds.), Perspectives on socially shared cognition (pp. 63-82). Washington, DC: American Psychological Association.

McGee, C. (1997). Teachers and curriculum-decision-making. Palmerston North, New Zealand: Dunmore.

Miller, J. (2000). The development of civic scientific literacy in the United States. In D. Kumar \& D. Chubin (Eds.), Science, technology and society: A source book on research and practice (pp. 21-47). Dordrecht: Kluwer.

Pilot, A., Bulte, M.W. (2006). What do you 'need to know'? Context-based education. International Journal of Science Education, 28(9), 953-956.

Preece, F.W., \& Baxter, J.H. (2000). Scepticism and gullibility: The superstitious and pseudo-scientific beliefs of secondary school students. International Journal of Science Education, 22(11), 11471156.

Sade, D., \& Coll, R.K. (2003). Technology and technology education: Views of some Solomon Island primary teachers and curriculum development officers. International Journal of Science and Mathematics Education, 1(1), 87-114.

Shamos, M. (1996). The myth of scientific literacy. Liberal Education, 82(3), 44-49.

Vygotsky, L. (1986). Thought and language. Translated by A. Kozulin. Cambridge, MA: MIT Press.

Wertsch, J.V. (1991). A sociocultural approach to socially shared cognition. In L.B. Resnick, J.M. Levine \& S.D. Teasly (Eds.), Perspectives on socially shared cognition (pp. 85-100). Washington, DC: American Psychological Association.

World Bank. (1996). Pacific island economies: Building a resilient economic base for the twenty-first century. Washington, DC: World Bank.

World Bank. (2006). Education for the knowledge economy. Retrieved 10 November 2006, from http://web.worldbank.org/WBSITE/EXTERNAL/TOPICS/

EXTEDUCATION/,,contentMDK:20161496 menuPK:540092 pagePK:148956 piPK:216618 the SitePK:282386,00.html

Yates, G.C.R., \& Chandler, M. (2000). Where have all the skeptics gone? Patterns of new age beliefs and anti-scientific attitudes in pre-service primary teachers. Research in Science Education, 30(4), 377-397.

\section{AFFILIATIONS}

Richard K. Coll

Centre for Science \& Technology Education Research

University of Waikato

New Zealand

\author{
Neil Taylor \\ School of Education \\ University of New England \\ Australia
}

